PressAcademia Procedia

Global Business Research Congress, June 4-5, 2020

\title{
AN OVERLOOK TO WORLD WINE INDUSTRY
}

\section{DOI: 10.17261/Pressacademia.2020.1271 \\ PAP- V.11-2020(43)-p.219-223}

Salih Kayikcioglu ${ }^{1}$, Umit Arikan ${ }^{2}$

${ }^{1}$ Yurtici Kargo, Istanbul, Turkey.

salih.kayikcioglu@yurticikargo.com, ORCID: 0000-0003-3187-5785

${ }^{2}$ Arikanli Holding, Istanbul, Turkey.

salih.kayikcioglu@arikanliholding.com, ORCID: 0000-0002-8005-5989

\section{To cite this document}

Kayikcioglu, S., Arikan, U., (2020). An overlook to world wine industry. PressAcademia Procedia, V.11, p. 219-223

Permemant link to this document: http://doi.org/10.17261/Pressacademia.2020.1271

Copyright: Published by PressAcademia and limited licensed re-use rights only.

\begin{abstract}
Purpose- The production of wine goes back 7000 years B.C. and wine has become a popular drink again today. This study aims to examine the trends of the winemaking sector in the world by mentioning a short history of winemaking.

Methodology- Statistical values such as world grape and wine production, wine consumption, total of exports and imports were collected from various sources, the changes in these values were analyzed by years and predictions were made about future predictions.

Findings- According to the analysis covering the years 2000-2016, in the period covering the last 17 years; Grape cultivation areas decreased by an average of $0.23 \%$ annually, while an average annual increase of $1.3 \%$ was achieved in the product bought due to the incre ase in productivity. While the global economic growth was $5.41 \%$ per annum in the analyzed period, an average annual growth of $6.46 \%$ was observed in value of wine exports.

Conclusion- As growth in the world economy is observed, the demand for wine increases faster than the world economic growth rate. While the value created in the world with wine production and trade was around 25 billion USD in year 2000, this value was about 65 billion USD in year 2016. In line with the increasing population, changing consumer preferences and economic growth, it can be predicted that the demand for wine consumption will increase all over the world and even create an increase in demand and economic value faster than the average World economic growth rate.
\end{abstract}

Keywords: History and production wine, wine, wine industry, prospects of wine industry.

JEL Codes: M10, M20, M21

\section{DÜNYA ŞARAPÇILIK SEKTÖRÜNE GENEL BIRR BAKIŞ}

\section{ÖZET}

Amaç- Tarihçesi M.Ö. 7000 yıl geriye giden şarap üretimi, günümüzde tekrar popüler bir içecek olmaya başlamıştır. Bu çalışma, şarap yapımının kısa bir tarihçesinden bahsederek, şarapçılık sektörünün Dünyada'daki gelişme trentlerinin incelemesini amaçlamaktadır.

Yöntem- Dünya üzüm ve şarap üretimi, şarap tüketimi, ülkelere göre dağılımı, ihracat ve ithalat toplamı gibi istatistiki değerler çeşitli kaynaklardan toplanarak, yıllara göre değişimleri analiz edilmiş ve gelecekte beklenen trantler hakkında öngörülerde bulunulmuştur.

Bulgular- 2000-2016 yıllarını kapsayan analize göre, son 17 yılı kapsayan dönemde; üzüm ekim alanları ortalam yıllık \%0,23 oranında azalırken, verimlilikteki artış nedeniyle alınan üründe ortalama yıllık $\% 1,3^{\prime}$ lük oranında artış sağlanmıştır. İncelenen dönemde Dünya ekonomik büyümesi yıllık ortalama \%5,41 olurken, şarap ihracatında ortalama yıllık \%6,46'lık bir büyüme görülmüştür.

Sonuç- Dünya ekonomisinde büyüme gözlemlendikçe, şaraba olan talep dünya ekonomik büyüme oranından daha hızlı artmaktadır. Şarap üretimi ve ticareti ile tüm dünyada yaratılan değer 2000 yilında yaklassık 25 milyar USD iken, 2016 yılında bu değer 65 milyar USD kadardır. Artan nüfus, tüketici tercihlerinin değişmesi ve ekonomik büyümeye parallel olarak, şarap tüketimine olan talebin tüm dünyada daha da artacağı ve hatta ortalama ekonomik büyüme oranından daha hızlı bir talep ve ekonomik değer artışı yaratacağı öngörülebilir.

Anahtar Kelimeler: Şarap yapımı ve tarihçesi, şarap, şarap sektörü, şarap sektöründe beklentiler.

JEL Kodları: M10, M20, M21

\section{GíRiş}

Bulunan tarihi kalıntılara bakıldığında tarih boyunca en eski içeceklerden birinin şarap olduğu bilinmektedir. Dolayısıyla, bir içecek olarak şarap ve bir üretim sektörü olarak şarapçılık insanlık tarihi kadar eskidir. Şarap yapımının başlangıcı kesin olarak bilinmemekle birlikte, tarihçesinin 7000 yıl öncesine kadar dayandığı tahmin edilmektedir. İlk şarabın bilinçli olarak üretilmediği ve bir şekilde kendiliğinden 
oluştuğunu gösteren bazı bilimsel verilere ulaşıımışır. Yapılan arkeolojik kazılar, ilk üzüm asması anavatanının Ön Asya olduğunu göstermekte olup; M.Ö. 4000'li yıllarda şarap yapıldı̆̆ı, daha sonra Hititler, Lidyalılar gibi diğer uygarlıklarda da şarap yapımının yayıldığı bilinmektedir (Çelik ve ark.2000). Arkeolojik kazılarda çıkarılan binlerce yıllık kadehler ve testiler, İyonya döneminden kalma amforalar, Hitit Krallarının Tanrılara şarap sunuşunu gösteren resimler, üzerinde üzüm salkımı bulunan Kilikya sikkeleri, efsaneler, yazıtlar, aslında binlerce yıllık bir bağcllık mirasının üstünde oturduğumuzu ve Anadolu topraklarının, bağcllık, şarap üretimi ve şarap ticaretinin önemli bir merkezi olduğunu işaret etmektedir.

Bazı araştırmacıların bulgularına göre, düzenli üzüm ekimi-biçimi, M.Ö. 7000 yıına kadar geriye gitmektedir. Eski Mısır'da duvarlarda şarap figürlerine rastlanmıştır. Mısırılırın ilk üzüm bağları, üreticileri, bağbozumu ve şarap etiketleri hakkında kayıt tuttukları görülmektedir. Babilliler ise, şarap dükkanlarının işletilmesi üzerine ilk kanunları çıkaran topluluk olmuştur. Daha sonra şarapçlık ve bağ cllık Ege kıyılarından, Yunanistan, İtalya, Fransa ve İspanya'ya kadar yayılmıştır. Milattan önce birinci yüzyılda Roma ve oradan da Fransa' ya ulaşana kadar Avrupa'da bağcılığın ve şarap üretiminin olmadığı bilinmektedir (Yıldız, 2009, s. 90). Avrupa'da bağ ve şarap kültürünün yayılmasında Romalıların büyük payıvardır. Kutsal bir içki olarak kabul edilen şarabı Roma Imparatorluğu, başta Fransa olmak üzere Tuna, Ren ve Basel nehirleri boyunca kurulan yerleşim birimlerine yaymışır. (Koçkar, 2006, s. 20).

Dünya'da çok geniş bir alanda yapılmakta olan bağcllıkta asma veya omca (Vitis sp.) denilen bitki yetiştirilmektedir. Milyonlarca yıl öncesine dayanan asmanın anavatanı konusunda birbirinden çok farklı görüşler bulunmaktadır. Asmanın çok büyük form zenginliği göstermesi sebebiyle, anavatanı olarak Kafkasya, Hazar Denizi' nin güneyi ve kuzey doğu Anadolu yöreleri gösteriliyordu. Fakat XX. Yüzyılda bu konuda yapılan jeolojik ve arkeolojik araştırmalar sonunda günümüzden yaklaşık 60 milyon yıl öncesin de bile asmanın dünyanın birçok yöresinde yetişmekte olduğu tespit edilmiştir. Dünyada bağclık genel olarak kuzey yarım kürede 20-52, güney yarım kürede ise 20-40 enlem dereceleri arasında yayıımış bulunmaktadır. Sıcaklık bağcılı̆ı̆n dünyada bu enlem dereceleri dışına doğru yayılmasını önleyen en önemli faktördür.

Bağcılık için yerkürenin en elverişli iklim kuşağı üzerinde bulunan ülkemiz, kültür asması (Vitis vinıfera L.) ve bağclık kültürünün anavatanı olması nedeniyle, zengin bir gen potansiyeline sahiptir. İklim koşullarının uygun olması ve asmanın heterozigotik yapısından dolayı çok geniş çeşit ve tip zenginliğine sahiptir.

Bu çalışmanın devam eden bölümünde, şarap üretimi ile iligli biilgiler verilmektedir. Sonraki bölümde, Dünya'daki üzüm ve şar ap üretim ve ihracatı ile ilgili genel trentler analiz edildikten sonra, şarap sektörünün geleceği hakkındaki öngörülerle bu çalısma sonuçlanmaktadır.

\section{2. ŞARAP VE ŞARAP ÜRETIMI}

Şarap, Saccharomyces Cerevisiae adlı mayanın üzüm suyundaki glikozu, etil alkole dönüştürmesinden meydana gelir. Diğer bir ifadeyle, şarap üzüm suyunda mevcut olan şekerin, üzümde doğal olarak mevcut olan mayaların veya kültür mayalarının yardımı ile etil alkole dönüşmesi sonucunda oluşan bir içkidir. Şarap üretimi aslında basit bir süreç gibi görünse de, üretim aşamasındaki dikkat edilecek ayrıntılar, şarabın tadına ve kokusuna etki etmektedir. En eski saklama metotlarından biri olan fermantasyon, insanlık tarihinin aslında en eski gıda işleme proseslerinden biridir. Glikozun etil alkole dönüşmesi ile oluşan şarap sadece bir içki değil, insan vücudu için de bazı faydaları olduğu söylenen bir gıdadır. Bir şişe şarabın vücutta yakılmasıyla, 650 kalori enerji açı̆̆a çıkmakta, bu da yaklaşık olarak $900 \mathrm{gr}$ süt, $385 \mathrm{gr}$ et, 5 yumurta veya $370 \mathrm{gr}$ ekmeğin verdiği kaloriye eşdeğer olmaktadır (Anonim, 1996). Kırmızı şarap ile beyaz şarap arasındaki en önemli fark ise, üretildikleri üzüm cinsinden çok, kullanılan üretim metodundan kaynaklanmaktadır. Beyaz şarapların genellikle beyaz üzümlerden, kırmızı şarapların da kırmızı üzümlerden yapılıyor olmalarına karşın, kırmızı üzümden beyaz şarap da üretilebilmektedir (Karaca, 2002).

Temel maddesi üzüm olan şarap, insanın ürettiği ilk fermente ürünlerden biridir. Üzüm tanesinin içinde yoğun olarak bulunan şeker, su ve kabuğundaki maya, doğal bir fermantasyon ortamı oluşturmaktadır. Olgun üzüm tanesinin patlatılmasıyla açığa çıkan şıranın, ka buktaki mayalar ile birleşip fermente olması sonucunda ortaya çıkan alkollü bileşim "şarap" olarak adlandırılmaktadır. Şarapçılık, şarap üretimine verilen addır. Şarabın yapılacă̆ı üzüm veya başka bir meyvenin seçimiyle başlar, yapımı biten şarabın şişelenmesiyle sona erer. Çoğu şarap üzümden yapılsa da, diğer meyvelerden veya zehirli olmayan bitkilerden de şarap yapılabilir. Örneğin, bal şarabının sudan sonraki en önemli malzemesi baldır. Üzüm, şarapta kalite kriterlerinde en önemli etkendir. Üzüm tanesi, tane sapı, sap çukuruve taneden meydana gelmektedir. Tane; tane kabuğu, meyve eti ve çekirdeklerden oluşmaktadır. Olgun bir tanenin, \%5-12'sini tane kabuğu oluşturmaktadır. Meyvenin üst kısmında ince, mumsu bir tabaka (pus) bulunmaktadır. Bu tabaka, olgun taneyi su kaybına ve mekanik zararlılara karşı korumaktadır. Kabuk aroma, renk ve tad maddelerinin büyük bir kısmını bünyesinde barındırmaktadır. Tanenin sulu kısmı, tane ağırlığının \%80-90'nını oluşturmaktadır. Tanede çekirdek sayısı 0-4 arasında değiş̧mekte, nadiren 6’ya kadar çıkabilmektedir. Şaraplık üzüm çeşidinde, kalın kabuk, küçük tane istenir. Tanede bulunan renk, tat ve aroma maddelerinin büyük çoğunluğu tane kabuğundaki hücre tabakalarında bulunmaktadır (Pinelo ve ark., 2006). Şarap üretiminde kullanılan başlıca yerli ve yabancı üzüm çeşitleri ve bu çeşitlerin özellikleri, aşağıdaki sunulmuştur (Anli, 2010; Denizer, 2012; Neiman, 2013).

Chardonnay- Fransa' da Bourgogne şarap bölgesinin dünyaca tanınmış şaraplık üzüm çeşididir. Avrupa'nın birçok ülkesinde bulunmaktadır. Harmanlanarak veya tek başına şampanya üretiminde kullanılmaktadır. Salkımlar orta büyüklük ile küçük arasında, silindirik konik veya silindirik formdadır. Taneler küçük küresel, transparan olgunluğa ulaşınca kalın kabukludur. Rengi yeşil-sarı renkte, sulu ve tatıdır.

Sauvignon Blanc- Fransa' da Bordeaux şarap bölgesinin dünyaca ünlü beyaz şaraplık üzüm çeşididir. Salkımlar küçük, kısa ve konik formdadrr. Taneler küçük, transparan, hafif oval ve olgunluğa ulaşıncaya kadar kalın kabukludur. Sauvignon Blanc şarapları genel olarak yeşil ot, kesilmiş ot, greyfurt ve kuşkonmaz aromalarının algılandığı şaraplardır. Fıçıda olgunlaştırmayla bu aromalara vanilya, meşe ve füme aromalar da eklenir.

Semillion- Bordeaux şarap bölgesinin önemli beyaz şaraplık üzüm çeşididir. Çok üst kalitede tatı beyaz şarap üretiminde kullanılır. Türkiye'de ise Trakya bölgesine ilk adapte edilen yabancı beyaz üzüm çeşitlerdendir. Taneler orta irilikte, yuvarlak, altın sarısı, yumuşak etli ve suludur. Şarabında karakteristik incir aroması vardır. 
Riesling- Almanya'nın Rheingau bölgesi kökenli, dünyaca tanınmış beyaz şaraplık üzüm çeşididir. Beyaz çeşitlerin kraliçesi olarak da bilinir. Küçük, yeşil-sarı renkte, güneşe bakan kısımlarında hafif siyahımsı çiller içeren, rengi sarı-kahverengine dönen tanelere sahiptir. Riesling şarabı meyvemsi, taze, canlı, diri, ve zariftir. Mükemmel içimli, kendine özgü bir bu- keye sahiptir. Özellikle "Eise Wein” (Buz Şarabı) dünyanın en özel şarap örneklerindendir.

Pinot Noir- Fransa' nın Bourgogne bölgesinin dünyaca tanınmış şaraplık üzüm çeşididir. Bordeaux bölgesi kırmızı şaraplarına göre daha az renk yoğunluğuna sahip şaraplar verir. Kiraz, ahududu, kırmızı meyvelerin ön burunda yoğun olarak algılandığı kompleks yapıda şaraplar verir. Almanya'da Spätburgunder, İtalya'da ise Pinot Nero olarak bilinir. Moldova, Dünya"ın en önemli Pinot Noir üretici ülkeler arasında yer almaktadır.

Cabernet Sauvignon- Fransa ve dünya şarapçıı̆ının en önde gelen kırmızı üzüm çeşitlerinden biri olan Cabernet Sauvignon, Bordeaux şarap bölgesinde üretilen kırmızı şarapların bileşimine en yüksek oranda giren çeşittir. Dünyanın farklı bölgelerinde de üretilir. Çoğunlukla tek çeşit şarap üretiminde kullanılır. Ancak, Kaliforniya'da Merlot, Avustralya' da ise Shiraz çeşidi ile olan harmanları büyük beğeni kazanmıştır. İtalya' nın dünyaca ünlü Super Toscana şarapların bileşiminde de bulunmaktadır. Ayrıca Chianti harmanına da çok düşük miktarda girmektedir. Salkımları küçük, siyah-mor renkte, küçük, kalın kabuklu tanelere sahip bir çeşittir. Şarapları gençken koyu yakut renginde, ön burunda frenküzümü, siyah kiraz ve böğürtlen yanında topraksı aromalarında algılandığı, damakta güçlü gövdesiyle dikkat çeker. Şarap meşe fıçıda olgunlaştıkça gelişir ve vanilya, sedir, kızarmış ekmek, yeşilbiber ve bazen farklı baharat aromalarının birlikte algılandığı karmaşık ve zengin bir şarap verir.

Merlot- Bordeaux şarap bölgesinin dünya çeşidi haline gelen üzümüdür. Bordeaux'nun Saint-Émilion ve Pomerol alt bölgelerinde üretilen kırmızı şarapların bileşimine giren temel üzüm çeşididir. Bölgenin diğer önde gelen üzümü olan Cabernet Sauvignon'a oranla daha ince kabuklu, dara iri tanelere sahiptir. Merlot çeşidinden yapılan şaraplar, Cabernet Sauvignon'a göre daha yüksek alkol derecesine çıkar. Aroması zengin, tanen oranı ise düşüktür. Yıllandıkça gelişir, zarafeti artar; çikolata, olgun kırmızı meyveler, toprak, mantar ve bahar çiçekleri ile bezenmiş bitkisel aromalardan oluşan mükemmel bir bukeye ulaşır. Fransa dışında Kaliforniya, Arjantin, Şili ve Güney Amerika ülkeleri, Yeni Zelanda ve Avustralya' da üstün nitelikli şarapların bileşimine girer.

Asma, dünya üzerinde kültürü yapılan en eski meyve türlerinden birisidir. İlk çağlardan beri kültüre alınan asma ve bağcılık kültürü, doğu ve batı medeniyetlerinin sosyal ve ekonomik yapısı içinde her dönemde önemli bir yer tutmuştur (Çelik ve ark., 1998). Bugün dünyada üzüm ve ondan elde edilen şarap kadar dikkat çekici bir başka ürün bulmak oldukça zordur (Ağaoğlu, 1999). Yöresel farklılıklar asmanın gelişimini, üzümün olgunlaşmasını, üzümün ve şarabın bileşimini ve duyusal özelliklerini etkilemektedir. Kalite şaraplar karakteristik özelliklerini yetiştiğ bölgeden almaktadır. Bağın bulunduğu bölge veya yöre koşulları (toprak, iklim, topoğrafik özellikler) şarabın kalitesini ve stilini belirleyen önemli faktörlerdir. Orijin kontrolünde temel alınan 'terroir' kavramı; üzümün yetiştiği bölgenin coğrafi, topoğrafik, iklimsel yapısı ve güneş ile ilişkisini tanımlamaktadır (Kayalar, 2015).

\section{DÜNYA ŞARAPSEKTÖRÜNE GENEL BAKIŞ}

FAO (Dünya Gıda Örgütü) verilerine göre; 2013 yılı verilerine göre dünyada 7 milyon 175 bin ha alandan üzüm tarımı yapılıp hasadı gerçekleştirilmiş olup, hasat gerçekleştirilen alanların \% 13,7' si İspanya' da \%10,5' i Fransa' da ve \% 10,2' si Çin' dedir. 2013 yılında 2000 yılına göre üzüm hasadı gerçekleştirilen alanda \% 2,5 oranında düşme gözlenirken, hasat gerçekleştirilen alanın en fazla artış gösterdiği ülke Çin olmuştur.

Avrupa Birliği içinde yer alan bağların miktarı, Avrupa komisyonun yayınladığı bağ alanlarının sınırlandırılmasını esas alan bir yönetmeliğe rağmen fazla etkilenmemiştir. Bu durum Avrupa bağlarının uzun dönemde alan bakımından dengede kalacağı anlamına gelmektedir. Eldeki mevcut veriler 2012-2013 yılları arasında, Portekiz, Romanya, Yunan ve Avusturya bağ alanlarında bir önceki yıllardaki hasat ile karşılaştırıldığında alan olarak sabit bir durumun olduğu öngörülürken, İspanya ve İtalya' daki geniş bağ alanlarında beklenildiği gibi bir düşüş olduğu gözlemlenmektedir. 2012 - 2013 yılları arasında geçmişte elde edilen verilere göre, bağ alanlarının 10000 ha ile 20000 ha arasında bir düşüş olduğunu göstermiştir. 2011 - 2012 yılları arasında ise aşağı yukarı 36000 ha lık bir azalmadan 2 kat daha az olduğu saptanmıştır.

TEPGE (Dünya Gıda, Tarım ve Hayvancllık Bakanlığı Tarımsal Ekonomi ve Politika Geliştirme Enstitüsü) verilerine göre, Dünya üzüm üretiminin yarıdan fazlası Avrupa Kıtası' nda gerçekleştirilmektedir. Eldeki verilere göre 2014/2015 üretim sezonunda; 20 milyon 554 bin ton sofralık ve 1 milyon 217 bin ton kuru olmak üzere toplam 21 milyon 771 bin ton üzüm üretimi gerçekleşmiştir. Sofralık üzüm üretiminin \% $43,8^{\prime}$ ini gerçekleştiren Çin 9 milyon ton ile ilk sırada, \% 12,2' sini gerçekleştiren Hindistan 2 milyon 500 bin ton ile ikinci sırada ve 1 milyon 920 bin ton ile üretimin \% 9,2' ünü gerçekleştiren Türkiye üçüncü sırada yer almaktadır. Üzüm hasat edilen alan bakımından önemli bir paya sahip olan İspanya ve Fransa gerek sofralık üzüm, gerekse kuru üzüm üretiminde verim düşüklüğü nedeniyle, üzüm üreticisi ülkeler arasında önemli bir yer edinememiştir. Dünyada sofralık üzüm üretimi 2000/2001 üretim sezonunda 8 milyon 604 bin ton iken, 2014/2015 sezonunda yaklaşk 1,5 kat artarak 20 milyon 554 bin tona ulaşmıştır. Güney yarım küre ülkelerinden Güney Afrika, Peru ve Arjantin' de sofralık üzüm üretimi de artmaktadır. Sofralık üzüm üretiminde dünya ikincisi olan Hindistan'da 2009/2010 üretim sezonunda, AB' de ise 2011/2012 ve 2012/2013 üretim sezonunda ciddi bir düşüş olduğu gözlemlenmiştir. 2014/2015 üretim sezonunda, bir önceki sezona göre ABD'de Kaliforniya'da çiçeklenme döneminde yağan dolu ve yaşanan kuraklıktan dolayı üzüm üretiminde \% 9' luk bir azalma meydana gelmiştir. Aynı dönemde Şili' de bazı üretim bölgelerinde yaşanan kuraklığa rağmen, üretim \% 14 artarak 1,2 milyon ton olmuştur. Türkiye'nin üretimi ise, ilkbahar mevsiminde yaşanan dolu don ve bunu takiben yaşanan yağışlardan dolayı \% 13 azalarak 1,9 milyon ton olmuştur.

Dünya sofralık üzüm üretiminin bir önceki üretim sezonuna göre 2016/17 üretim sezonunda 22,7 milyon ton olarak gerçekleşmiştir. Dünya üzüm ticareti hacminin ise 3 milyon ton olarak gerçekleşmiştir. Çin hala Türkiye' nin önünde üretimini artırarak Asya pazarının en önemli tedarikçisi durumundadır. Çin 350 bin ton'luk ihracatını, Tayland, Vietnam ve Malezya gibi ülkelere gerçekleştirerek bu ülkeler için ucuz (0,5 $\$ / \mathrm{kg}$ ) üzüm tedarikçisi haline gelmiştir. Avrupa Birliği'nin büyük üzüm üreticileri olan İtalya ve Yunanistan'da 2015-2016 üretim sezonunda yaşanan olumsuz mevsimsel koşullar nedeni ile üretim azalarak, 1.7 milyon ton olmuştur. 2016-2017 üretim sezonunda ise, Avrupa Birliği 
ihracatının 84 bin ton, ithalatının ise 610 bin ton düzeylerinde olduğu görülmektedir. 2016-2017 sezonunda ABD sofralık üzüm üretimi 60 bin ton artarak 1 milyon ton olmuştur. İhracatı 37 bin ton artarak 365 bin ton olmuştur. İhracat büyük oranda Asya pazarına yapılmaktadır. ABD ithalatı 15 bin ton artarak 545 bin ton olmuştur. İthalat daha çok Şili' den küçük tedarikçiler aracılığı ile yapılmaktadır.

1998-2003 döneminde dünya şarap satışlarının \%12 oranında yükseldiği gözlemlenmiştir. Özellikle İtalya, Fransa, Portekiz ve İspanya gibi şarap tüketiminde belirleyici olan ülkelerde genç nüfusun geleneksel şarap içme alışkanlıklarını değiştirmeleri şarap tüketiminde farklılıklara sebep olmuştur, bu yüzden de özel günlere yönelik tüketimde artış gözlenmiştir. 1975 yılında Fransa ve İtalya' nın dünya pazarındaki payı \%50 civarında iken 2010 yılında bu oran \%25" kadar gerilemiştir. Bu durumda dünyanın diğer ülkelerininde piyasaya girmiş olmaları da dikkate alınmalıdır. Örneğin ABD’nin, Avustralya'nın ve Güney Afrika' nın, pazara sundukları yeni ürünler ve yenilikçi yaklaşımları ile dünya şarap pazarındaki payları yükselmektedir.

Dünya çapında yüksek kaliteli şarapları ile tanınan Fransa ve İtalya, 2006-2010 yılları arasındaki üretim düzeyleri ile dünya üretiminde ilk sıralardadır. Yapılan tahminler 2013 yılı şarap üretiminin 2012 yılına göre \% 10 kadar daha fazla olacağı ve 276,5 ile 285,4 milyon hl arasında gerçekleşebileceği yönündedir. 2012 yılı şarap üretimi 258,3 Mhl ile oldukça düşük bir yıl olarak göze çarpmaktadır. 2013 yılı ortalamanın üzerinde bir yıl olup buna yakın bir üretimi ise son zamanlarda 2006 yılında 282,6 Mhl ile görmekteyiz. Ancak 2006 yılında dünya bağ alanları da 7.799.000 ha kadardı ve 2013 yılına göre tahminen 300.000 ha daha fazlaydı bu da göz ardı edilmemesi gereken bir konudur. 28 Avrupa Birliği üyesi ülkede toplam olarak şarap üretimi 163,9 Mhl olmakta ve normal bir yıl olan 2012 yılına göre \%11'lik artış kaydedilmektedir. Bu üretim miktarı 164,9 Mhl' lik 2009 yılıyla da oldukça benzeşmektedir.Avrupa Birliğinin dışında kalan ülkelerdeki şarap üretimi 2008 -2012 yılları arasında oldukça durağan bir seyir izlemektedir. 2013 yılının tahmini rakamlarına bakıldığında 7 Mhl'lik bir fazla üretim beklenilmekte ve bu 2012 yılına göre \%12' lik bir artışa tekabül etmektedir.

ABD şarap üretim miktarlarında özellikle de Californiya'da 2013 yılı için 2012 yılına göre açık bir üretim artışı olacağı görülmektedir. 2012 yılında ABD'nin şarap üretim miktarı 20,5 Mhl olmuş ve 2013 yılı üretim miktarı ise $22 \mathrm{Mhl}$ olarak tahmin edilmektedir. Güney Amerika özellikle Brezilya'da şarap üretiminin $3 \mathrm{Mhl}$ ortalama seviyelerde olması beklenmektedir. Ancak ünümüzdeki süreçte üretimlerini artıracakları düşünülmektedir. Önde gelen üretici ülkelerden Şili' de 12,8 Mhl ile artış devam etmekte ve yeni bir rekor gerçekleşmektedir. Arjantin' de yine üretim artışı sürmekte 2012 yılında 11,8 Mhl'lik üretim miktarından \%27'lik artışla 15 Mhl'lik bir üretim miktarına çıkış gözlemlenmektedir. Okyanusya ülkeleri Avustralya ve Yeni Zelanda' nın 2013 yılı üretimlerine bakıldığında sırasıyla 13,5 Mhl ve 2,5 Mhl'lik şarap üretimlerinin 2012 yılına göre kayda değer bir artış gösterdikleri söylenilebilir. Bu ülkelerde 2011-2012 yıllarında önemli miktarlarda alan azaltmasına gidilmesine rağmen meydana gelen üretim artışı büyük önem arz etmektedir. Önemli bir şarap üreticisi olan Güney Afrika Cumhuriyetinde ise 2013 yılı üretimi $11 \mathrm{Mhl}$ olup 2012 yılına göre \% 3,8' lik artış kaydedilmiştir. Üretimin önümüzdeki süreçte de bu şekilde devam edeceği öngörülmektedir.

Uluslararası Bağcılık ve Şarap Örgütü’nün (OIV - Organisation Internationale de la Vigne et du Vin) tarafından Haziran 2019' da yapılan genel kurul toplantısında yayınlanan verilere göre, dünyada en yüksek miktardaki üzüm bağları Avrupa kıtasında bulunmaktadır. Avrupa, zengin bağcılık ve şarapçılık tarihi ve gelişmiş üretim ile bağcılık ve şarapçılığın merkezi konumundadır. Ancak bununla birlikte, Avrupa kıtasındaki bağcılık arazilerinin son yıllarda azaldığı görülmektedir. 2018 yılı verilerine göre, bağcılık alanlarında özellikle İspanya'da 969.000 hektar ve Fransa' da 93.000 hektar azalmak görülmüştür. (OIV, 2019).

Dünya genelinde şarapçılık sektörü son yıllarda uluslararası karakterini güçlendirmiş ve sayıları gün geçtikçe artan farklı bölgesel oyuncular ve piyasaya sürülen farklı ürünler ile zenginleşmiştir. Küresel şarapçılık pazarında hiçbir büyük firma \% $1^{\prime}$ den daha büyük paya sahip değildir. Ancak piyasada büyük oyuncuların devralma ve satın alma yolu ile pazar paylarını yükseltme gayesinde oldukları da gözlemlenmektedir. Dünyanın en büyük şarap ihracatını Avrupa kıtası ger çekleştirmektedir. Dünya pazarının \%60'ının beş ihracatçı ülkenin (Fransa, İspanya, İtalya, $A B D$, Avustralya) kontrolünde olduğu görülmektedir. Ancak Avrupa şaraplarının ihracatında görülen belirgin düşüşün en büyük nedeninin Avrupa şarap sektörünün küresel yenilikçi şarap pazarına uyumda karşılaştığı sorunlardan kaynaklandığı söylenebilir. Özellikle ABD, Güney Afrika ve Avustralya menşeli ürünlerin dünya piyasalarında çoğalması ve bu bölgelerden kaliteli şarap üretimi ve markalaşma sürecini başarı ile tamamlamış firmaların çıkması rekabeti artırmaktadır.

Tablo 1: Dünya Şarap Sektöründe Genel Trentler

\begin{tabular}{|c|c|c|c|c|c|c|c|c|c|c|c|c|c|}
\hline \multirow{19}{*}{ 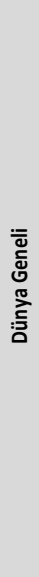 } & YıI & $\begin{array}{c}\text { Şarap } \\
\text { Üretimi } \\
1000 \mathrm{hl}\end{array}$ & $\begin{array}{c}\text { Büyüme } \\
\text { Hızı \% }\end{array}$ & $\begin{array}{l}\text { Üzüm } \\
\text { Bağları } \\
\text { hektar }\end{array}$ & $\begin{array}{c}\text { Büyüme } \\
\text { Hızı \% }\end{array}$ & $\begin{array}{l}\text { Elde Edilen } \\
\text { Ürün }\end{array}$ & $\begin{array}{l}\text { Büyüme } \\
\text { HIzı \% }\end{array}$ & $\begin{array}{c}\text { Şarap } \\
\text { Ihracatı } \\
1000 \mathrm{hl}\end{array}$ & $\begin{array}{c}\text { Büyüme } \\
\text { Hızı \% }\end{array}$ & $\begin{array}{l}\text { Şarap } \\
\text { İhracatı } \\
\text { Milyar } \\
\text { USD }\end{array}$ & $\begin{array}{c}\text { Büyüme } \\
\text { Hızı \% }\end{array}$ & $\begin{array}{l}\text { GDP } \\
\text { Trilyon } \\
\text { USD }\end{array}$ & $\begin{array}{c}\text { Büyüme } \\
\text { Hizı \% }\end{array}$ \\
\hline & 2000 & 278918 & & 7254172 & & 87608 & & 60291 & & 12,7 & & 33,58 & \\
\hline & 2001 & 265523 & $-4,80$ & 7284833 & 0,42 & 83546 & $-4,64$ & 65144 & 8,05 & 12,7 & 0,00 & 33,39 & $-0,57$ \\
\hline & 2002 & 257380 & $-3,07$ & 7340667 & 0,77 & 83323 & $-0,27$ & 67893 & 4,22 & 14,2 & 11,81 & 34,67 & 3,83 \\
\hline & 2003 & 264296 & 2,69 & 7389167 & 0,66 & 85329 & 2,41 & 72495 & 6,78 & 17,3 & 21,83 & 38,90 & 12,20 \\
\hline & 2004 & 297792 & 12,67 & 7285772 & $-1,40$ & 92245 & 8,11 & 76613 & 5,68 & 19,8 & 14,45 & 43,81 & 12,62 \\
\hline & 2005 & 277684 & $-6,75$ & 7283439 & $-0,03$ & 91956 & $-0,31$ & 78970 & 3,08 & 20,6 & 4,04 & 47,45 & 8,31 \\
\hline & 2006 & 282818 & 1,85 & 7311709 & 0,39 & 91610 & $-0,38$ & 84358 & 6,82 & 22,5 & 9,22 & 51,44 & 8,41 \\
\hline & 2007 & 268077 & $-5,21$ & 7233057 & $-1,08$ & 91855 & 0,27 & 88941 & 5,43 & 27,3 & 21,33 & 57,96 & 12,67 \\
\hline & 2008 & 269191 & 0,42 & 7134317 & $-1,37$ & 93570 & 1,87 & 89777 & 0,94 & 29,6 & 8,42 & 63,61 & 9,75 \\
\hline & 2009 & 269361 & 0,06 & 7107393 & $-0,38$ & 95641 & 2,21 & 88219 & $-1,74$ & 25,2 & $-14,86$ & 60,33 & $-5,16$ \\
\hline & 2010 & 262657 & $-2,49$ & 7010474 & $-1,36$ & 95699 & 0,06 & 95984 & 8,80 & 27,9 & 10,71 & 66,05 & 9,48 \\
\hline & 2011 & 267509 & 1,85 & 6981942 & $-0,41$ & 100018 & 4,51 & 103369 & 7,69 & 32,3 & 15,77 & 73,39 & 11,11 \\
\hline & 2012 & 260030 & $-2,80$ & 6972269 & $-0,14$ & 99076 & $-0,94$ & 103243 & $-0,12$ & 32,8 & 1,55 & 75,08 & 2,30 \\
\hline & 2013 & 291008 & 11,91 & 7094458 & 1,75 & 108539 & 9,55 & 101604 & $-1,59$ & 34,7 & 5,79 & 77,24 & 2,88 \\
\hline & 2014 & 269806 & $-7,29$ & 7020630 & $-1,04$ & 106509 & $-1,87$ & 103959 & 2,32 & 34,6 & $-0,29$ & 79,33 & 2,71 \\
\hline & 2015 & 275207 & 2,00 & 7092238 & 1,02 & 107620 & 1,04 & 105619 & 1,60 & 31,7 & $-8,38$ & 75,05 & $-5,40$ \\
\hline & 2016 & 270096 & $-1,86$ & 6990219 & $-1,44$ & 107281 & $-0,31$ & 103805 & $-1,72$ & 32,3 & 1,89 & 76,16 & 1,48 \\
\hline & Ort. & 271777 & $-0,05$ & 7158287 & $-0,23$ & 95864 & 1,33 & 89375 & 3,52 & 26 & 6,46 & 59,62 & 5,41 \\
\hline
\end{tabular}


Dünya şarap sektörü ile ilgili 2000-2016 yılları arasındaki son 17 yıllık gelişmeler yukarıdaki Tablo 1'de görülmektedir. Son 17 yılda Dünya' daki üzüm bağları ortalama \%0,23 oranında azalma olmuştur. Buna karşılık, hektar başına üzüm üretim verimliliğinde \%1,33 oranında bir artış olurken, şarap üretiminde ortalama yıllık \%0,5'lik bir azalma gözlemlenmiştir. Diğer yandan, ihraç edilen litre şarap miktarında yıllık ortalama \%3,52'lik bir atış olurken, değer olarak (USD) şarabın yıllık ortalama ihracat artışı \%6,46 olmuştur. Bu durum, şarabın litre başına değerinin, ihraç edilen miktarına göre iki kat daha hızlı arttığı söylenebilir. Ayrıca, 2000-2016 yıllarını kapsayan 17 yılı dönemde Dünya ekonomisi yıllık ortalama \%5,41 oranında büyümüştür. Ortalama yıllık şarap ihract artışı ile ortalama yıllık Dünya ekonomik büyüme oranları karşılaştırıldı̆̆ında, şarap ihracat değer artış hızının, Dünya ekonomik büyüme hızının yaklaşık iki katı kadar olduğu görülmektedir.

\section{SONUÇ VEÖNERILER}

Dünyada, şarap yapımında kullanılan 400' ün üzerinde üzüm çeşidi bulunmakta ve her yıl ortalama 25-30 milyar litre kadar şarap piyasalara arz edilmektedir. Dünyada, kişi başına düşen yıllık ortalama şarap tüketim miktarı, 3-4 litre arasında değişmektedir. Bu rakam, Türkiye'de gerçekleşen kişi başına ortalama yıllık şarap tüketiminin, yaklaşık dört katı kadardır. Fransa ve ittalya gibi ileri şarap ülkelerinde kişi başına yıllk tüketim ise, 60 litre düzeyine ulaşmaktadır (Aktan ve Kalkan, 2000; Anlı, 2005). Kaliteli şarap, kaliteliüzümden elde edilir. Şarabın hammaddesi olan üzümün bileşimi; çeşide, yetişme yılına, yetişme bölgesine; yetişme bölgesinin toprak, iklim koşulları vb. faktörlerden etkilenmekte ve değişim göstermektedir (Ekşi, 1989). Son yıllarda alkollü içecekler içerisinde şaraba olan genel talep ve özellikle genç kuşaktan olan talep, hızla artmaktadır.

Dunyadaki toplam üzüm üretim alanları ve üzüm uretimi azaldığı halde, verimlilik ve talep artışı nedeniyle daha cok sarap üretimi ve piayasalara arzı yapılmaktadır. Dünya ekonomisinde büyüme gözlemlendikçe, şaraba olan talep dünya ekonomik büyüme oranından daha hızlı artmaktadır. Şarap üretimi ve ticareti ile tüm dünyada yaratılan değer 2000 yılında yaklaşık 25 milyar USD iken, 2016 yılında bu değer 65 milyar USD kadardır. Artan nüfus, tüketici tercihlerinin değişmesi ve ekonomik büyüm eye parallel olarak, şarap tüketimine olan talebin tüm dünyada daha da artacağı ve hatta ortalama ekonomik büyüme oranından daha hızlı bir talep ve ekonomik değer artışı yaratacağı öngörülebilir.

\section{KAYNAKÇA}

Ağaoğlu, Y.,S. 1999. Bilimsel ve Uygulamalı Bağcılık. Kavaklıdere Eğitim Yayınları. No: 1. $614 \mathrm{s.}$

Aktan, N., Kalkan, H. 2000. Şarap Teknolojisi. Ege Üniver - sitesi Mühendislik Fakültesi Gıda Mühendisliği Bölümü.Kavaklıdere Eğitim Yayınları No:4, 6145, Ankara.

Anlı, R.E. 2005. Ansiklopedik Şarap Sözlüğü, Kavaklıdere Eğitim Yayınları, 256s.,

Anlı, E. (2010). Şarap Tadımı. Inkılap Kitapevi, İstanbul.

ANONIM, 1996, Şarap Hakkında Özel Bilgiler, Tekel Tekirdağ İçki ve Şarap Fabrikası, Tekirdağ

Anonim, 2013 Yılı Çekirdeksiz Üzüm Raporu, Gümrük ve Ticaret Bakanlığı Kooperatifler Genel Müdürlüğü, Şubat 2014,

Çelk, H., Marasalı, B., SöylemezoğLu, G., Tangolar, S. ve Gündüz M., 2000. Bağclıkta üretim hedefleri. TMMOB Ziraat Mühendisleri Odası V.Türkiye Ziraat Mühendisliği Teknik Kongresi. 17-21 Ocak, 645-678s, Ankara.

Denizer, D. (2012). Yiyecek-İçecek Hizmetleri. Anadolu Üniversitesi Yayını No: 2540, Eskişehir

EKŞi, A., 1989. Gıdalarda kimyasal bilesim değisimleri ve kontrolü. Birinci Uluslar Arası Gıda Sempozyumu, Uludağ Üniversitesi Ziraat Fakültesi Yayını, 89- 96s., Bursa. Karaca U. (Ağutos, 2002), Şarap Üretimi, Türkiye' de Şarapçılık ve Cupratol Yöntemi İle Şarapta Bakır Tayini, İstanbul Teknik Üniversitesi-Kimya Metalorji Fakültesi Yüksek Lisans Tezi

FAO (Food and Agriculture Organization Of The United Nations) Kayıtları, 2014. (http://faostat.fao.org), (Erişim Tarihi: 20.02.2014).

FAOSTAT (Food and Agriculture Organization Of The United Nations) Kayıtları, Çeşitli Yıllar, (http://faostat.fao.org), (Erişim Tarihi: 20.02.2014).

Kayalar, M. 2015. Tokat Ilinde Farklı Yörelerde Yetiştirilen Narince Üzüm Çeşidinden Üretilen Şarapların Bazı Kalite Özelliklerinin Belirlenmesi. (Yüksek Lisans Tezi), Gaziosmanpaşa Üniversitesi, Fen Bilimleri Enstitüsü, Gıda Mühendisliği Anabilim Dalı, Tokat.

Kavaklıdere Yayınları, 2003, Şarabın A B C'si

Koçkar, M. (2006). Şarabın Gizli Renkleri. Ada Yayınları.

Neiman, O. (2013). Le Vin C'est Pas Sorcier. Nail Kitapevi, İstanbul.

Pinelo, M., Amous, A., Meyer, A.S. (2006). Food and Bioproducts Processing Lyngby, Denmark

http://www.oiv.int/public/medias/6782/oiv-2019-statistical-report-on-world-vitiviniculture.pdf $\quad$-07.02.2019

http://www.oiv.int/public/medias/6782/oiv-2019-statistical-report-on-world-vitivin iculture.pdf-07.02.2019

http://apelasyon.com/Yazi/122-dunya-sarap-uretim-ve-tuketiminde-son-yillarda-yasanan-gelismeler-

(02.11.19 tarihinden itibaten günceldir.)

http://apelasyon.com/Yazi/707-dunyada-ve-turkiyede-saraplik-uzum-piyasalari (30.11.2019)

https://databank.worldbank.org/indicator/NE.EXP.GNFS.ZS/1ff4a498/Popular-Indicators-07.02.2019 